\title{
The Laugh of the Medusa and the Ticks of Postmodern Feminism: Helen Cixous and the Poetics of Desire
}

\author{
Mohamed Hamoud Al-Mahfedi \\ Assistant Professor of English, Department of English, Al-Baydha University, Yemen. \\ Mahfadi76@yahoo.com
}

\begin{tabular}{ll}
$\begin{array}{l}\text { Received: } \\
\text { 11/06/2019 }\end{array}$ & This paper aims to explore Helen Cixous' postmodernist trends in her \\
\hline Accepted: & formulations of a new form of writing known as ecriture feminine. It attempts to \\
$\mathbf{2 2 / 0 6 / 2 0 1 9}$ & validate the view that Cixous' "The Laugh of the Medusa" is regarded as the \\
& manifesto of postmodern feminism. This is done by attempting a critical \\
& discourse analysis of Cixous' narrative of ecriture feminine. Deploying a \\
\hline Keywords: & multifaceted-framework, ranging from postmodernism to psychoanalysis \\
Postmodernism, & through poststructuralist theory and semiotics, the study reveals Cixous' \\
Feminist Theory, & metamorphosing and diversified trend of feminist writing that transposes the \\
Psychoanalysis, & subversion of patriarchy into a rather bio-textual feminism, known as \\
Deconstruction, & bisexuality. The paper highlights the significance of Cixous' essay as a \\
Cultural Theory, & benchmark of postmodern feminism. \\
Semiotics, Lacan, &
\end{tabular}

\section{INTRODUCTION}

From the title itself, Cixous made it clear that the main objective of her argument is to deconstruct the very idea stated by men about women. She has made this by referring to the myth of Medusa (in Greek mythology, Medusa was the enemy of Athens and others, and then changed into a person whose hair consisted of hissing snakes. She became so horrendous that the mere sight of her would turn men into stone.) Cixous allusively refers to her when she writes "woman too dark to be explored" and ends the essay by referring to the myth of Dora. Cixous politicizes her poetics in representing her ideal of the woman by treating it within the scale of freedom struggle and historical reclaiming. "The Laugh of Medusa" is located within a multi-Cixousian scheme: to "liberate", to "subvert" and to "invent". The effective weapon she boastfully uses is "L'écriture feminine". By "L'écriture feminine", Cixous foresees the end of patriarchy. The notion of writing as liberation is the basis of Hélèn Cixous's concept of l'écriture féminine. The whole concept is not free from its political implications. As remarked by Snežana Žabić, Cixous' feminist theory recognizes patriarchy is specifically cultural and historical context with power relations that are not universal, but nonetheless a real condition and that these do not exist separately from aesthetics and poetics. (Žabić , 2001, p. 3)

Hence, Cixous expresses the need to put an end to patriarchy for the last time. Cixous theory vehemently expresses her demand to destroy patriarchy, not to reform it, soften or replace it with matriarchy. Her idea is that the woman is to imagine and create a world with a completely different kind of economy, human relations, and language. Consequently, Cixous radically resorts for using the word phallocentrism, not patriarchy. Phallocentrism is a much wider concept that includes discourses such as philosophy.

What Cixous is saying is that women are made to accept this "reality", and therefore, they should "unlearn" it. As a start, she insists that women can make an effort to reject the 
language of oppression, tell the stories "differently" and the reality will start to transform too. Cixous' definitely experimental essay rejects genre classification, subverts phallocentrism and offers liberating ideas about women and the practice of writing. She claims that history has never produced, recorded anything but "Phallocentrism"; Phallocentrism is the enemy and it is time now to transform and invent the other history. So, she sees the system of phallocentrism as "a machine turning out its Truth", a machine that functions this way: “... starting with the abasement of woman. Subordination of the feminine to the masculine order which appears to be the condition for the function of the machine". (Sellers, 2003, p. 289)

Cixous's metaphor of phallocentrism as a machine is a troupe of those who are subordinated in that "machine" of phallocentrism, i.e. women, are actually themselves part of it because they keep it going too. The breaking of it comes not from those who are privileged. The breaking starts when women become conscious of the way they are interiorized and used in the symbolic and the social hierarchy, and when they act against the hierarchies themselves. In Cixous's opinion, one way to act is to write.

I shall speak about women's writing: about what it will do. The woman must write herself: must write about women and bring women to writing, from which they have been driven away as violently as from their bodies . . . The woman must put herself into ... by her own movement. (Cixous , 1976, p. 875)

By "write herself", is break away from the projected stereotypes the phallogocentric society and culture. Writing should be close to the body and desire. "I, too, overflow," declares Cixous, "my desires have invented new desires. My body knows of unheard-of songs." This Cixousian trajectory of feminine writing transcends the logo into the symbolic sort of thinking/ feeling act into body poetic-politics. Writing and the self, the subjective and the objective, the being and the symbolic, the signifier and the signified are identical. She declares; "Write! Writing is for you, you are for you; your body is yours". Hence, this new women's writing promotes a wider postmodern feminist discourse of imagined space, body space as a metaphor for action, rebellion in the larger simulated contours. Such a Cixousian trend claims a new historicist notional frame of text relocation within a historical experience of power-relation. In her feminist critique of the system, Cixous recalls the older condition of the subordination of the poor people to the rich, the persistent subordination of the gay/ lesbian/ queer people to the heterosexuals and the curious subordination of both the young and elderly people to the people "in their prime".

For Cixous, the woman is a text of multiple pleasures. She prophetically voices: "Write yourself. Your body must be heard." She refers to the sensual and sexual pleasures inscribed in women's texts. Feminine sexuality, for her, has been socially repressed together with feminine writing as an artistic expression or articulation of women's political and social presence. This feminine power has to be reclaimed and inscribed into writing.

I enter into myself with my eyes closed, and you can read it. This reading is performed here, by the being-who-wants-to-be-born, by an urge, something that wants at all costs to come out, to be exhaled, a music in my throat that wants to resound, a need of the flesh then, that seizes my trachea, a force that contracts the muscles of my womb and stretches my diaphragm as if I were going to give birth through my throat, or come. And it's the same thing. (Cixous, 1991, p. 52)

Cixous's concept of a libidinal economy is a challenging, complex concept here. It has its parallels in the literary theory. "[T] he point of intersection of Cixous's theory and the literary history is the notion of writing as almost a bodily endeavour." (Žabić, 2001, p. 6) It is 
on this basis that Cixous's theory mostly rests. She remarks that in the symbolic as in the realized world, the symbolic power over the text is similar to the power of the Father. A "man of letters' is simultaneous, like his divine counterpart, a father, a master or ruler, and an owner" (Porsdam, 2016, p. 201). That is the absence of femininity is not only in men's writing but also in female's texts too. She claims: "Nearly the entire history of writing is confounded with the history of reason. . . It has been one with the phallocentric tradition. It is indeed that same self-admiring, self-stimulating, self-congratulatory phallocentrism." (Warhol et al., 1997, p. 350)

To undo the historical claim of patriarchy, Cixous invokes the myth of "mother" as a symbol of rebirth, continuity and regeneration. A transcendentalist idea in a Lacanian frame is that Cixous struggles to introduce here. Thus, from the myth of Devi, Mata, and Zeus, and the role that the society reserves for the Mother, to pass on patriarchy to a new generation, to Madusa, Cixous redefines the Freudian model which defines "woman as lack", and instead celebrates "woman as excess" using the myth of Dora (i.e. a mythological figure who continues to haunt patriarchy), the hysteric, as an example of a woman who speaks her body and threatens patriarchy. Hence, the mother's milk becomes the white ink women write in. For Cixous, the feminine gift is always like mother's milk: it is a good exchange, because the return is in the gift itself, in the pleasure of giving. "Writing, too, is milk . . The more you give, the more you take pleasure." (Cixous, 1991, p.49)

Cixous uses the socio-political myth to display the subordination of the phallogocentric world. This is apparent in her reconstruction of Freud's psychoanalytical analysis of the castration complex. Men are afraid of women, afraid of losing their masculinity. They see women as a threat to them, so they turn for the use of power and control. They conceive Medusa as "fearful" and Dora as "hysteric". This is similar to the idea of litost, which is a state of torment created by the sudden sight of one's own misery. It is related to power. Cixous rejects the idea of defining woman in opposition to the man in terms of lacking. She refuses the idea of castration, which defines a woman as lacking and thus passive. Rather, she triumphantly declares that woman experiences desire in a holistic manner through the whole body. Woman's desire is various. In such a sophisticated way, Cixous signifies the hope of the change from the dim and dark image of a woman in the past to the anticipated bright future.

The unconscious, in Cixousian sense, is associated with the repressed, and thus with the feminine as well as other colonized places, such as Africa. Thus, her theory of "feminine writing" provides an escape from systems of cultural, religious, sexual and linguistic oppression. She insists that language and sexuality are inextricably linked, and that to free one means the freedom of the other. She associates feminine writing with the unconscious. The body speaks what the conscious mind could not say. Therefore, the paralysis of the limb represents the idea of a repressed mind.

Cixous theorizes women's writing in terms of the physical act of writing. By the feminine writing, she strives for the erasure of gender differences, for open-ended textuality, for the erasure of the phallogocentric dominion. Bisexuality for her is "a real liberation of sexuality, that is, a transformation of our relationship to our body and to another body". Cixous' notion of bisexuality is situated in the poststructuralist concept that language that is based on oppositions (male/female, presence/absence, phallus /hole) reproduces a patriarchal order, which places the feminine as subordinate to the masculine. This poststructuralist framework helps her in calling for a definition of bisexuality, which is not about the combination of sexualities, but the displacement of the terms "masculinity", and "femininity." 
Therefore, "Bisexuality" goes beyond dualism to suggest multiple subjects. This is what Cixous means when she asks women to "think differently" about their histories, not simply in the sense of origins, but in terms of language. Women must invent another history, which figures itself in their language and on their bodies.

\section{CIXOUS' POSTMODERNIST TICS IN "THE LAUGH OF THE MEDUSA"}

Cixous' essay gives macro examples of politico-economic myth-like stories that have inscribed on our bodies and that make up our "governing" political and economic discourses. The essay highlights the poetics of the body economics. "Perhaps the imagination is on the verge of recovering its rights," wrote Andre Breton, "We are still living under the reign of logic, but the logical processes of our time apply only to the solution of problems of secondary interest" (Waldberg, 1965, p.66). Poetics, as the concept is used here, refers to biospirituality. Bio-spirituality is also described as the pre systemized energy of the singularity of a person, as boundary exceeding, and so on. This concept is well celebrated and elaborated by Cixous in "The Laugh of the Medusa" as a foundational concept of Somatic discourse. The feminine discourse is intimately involved with somatic writing because genuine laughter emanates from within the body and because the aim of both a discourse of laughter and somatic writing is to liberate from encrusted and disabling meanings. Somatic discourse aims to derive energies and understandings from the libidinal. The Somatic Writing turns more attention to bodies and how we can unbridle the bridled. The breakdown of established meanings through laughter, as the first step toward liberation, is the basis of "The Laugh of the Medusa" (Conley, 1992, p. 34). In Cixous' account, the established meanings include the understandings developed about the nature and functioning of women-frozen into place "between two terrifying myths: between the Medusa and the abyss . . . It would be enough to make half the world (i.e., women) break out laughing, if it were still not going on" (Cixous \& Clement, 1986, p. 68). But the main function of laughter in the Cixousian scheme is to liberate us - men and women - from the established set of meanings, which not only oppress but also distort and limit understandings.

Within the convoluted postmodern de-centered and floated identity, the female body and sexuality in writing became a signifier, and her voice as a play, a sign of a signaling power, an expression that cannot be coded or theorized. Cixous uses the word "woman" as a foregrounding term: plural in meaning, theoretical in the proposition and a play in writing. She de-familiarizes it and reinvents its totality. She deploys the motif of Medusa as a metaphor for women's multiplicity that opposes patriarchal strictures on women's body and voice. She writes:

'woman', we still don't know what that means, even if we know what we want to mean ... In any case, she is not a woman. She is plural. Like all living beings, who are sometimes invaded, drawing life from others, giving life. Who do not know themselves." (Bray, 2004, p. 1)

Cixous' essay is invested with repulsive spirit against focalization and singularity. She revealed her discontent of misogyny when she writes: "I abruptly learned that my unacceptable truth in this world is being a woman. Right away, it was war. I felt the explosion, the odour of misogyny." (Sellers, 2003, p. 12) Her multicultural diasporic experience and academic background as a teacher of criticism, besides her "belief in the power of language and of hopes of shattering of oppressive structures", ignited in her a revolutionary mood of rejecting fixities of given forms and ideas (Conley, 1992, p. 1).

Before delving into the textual reading of the essay, it is worth noting that Cixous' essay "The Laugh of the Medusa" is not easy because of its complex texture and allusions. It 
includes highly loaded and ideological terms. It requires a previous knowledge and comprehension of those terms and concepts without which the entire essay becomes a sort of a puzzle. Besides, Cixous has fused three critical approaches (psychoanalysis, deconstruction and structuralism) together in her essay which adds to the complexity of the text. The essay shows the great influence of the leaders of those schools of criticism, such as Sigmund Freud, Jacques Derrida, Ferdinand de Saussure, Jacques Lacan and others.

Cixous' feminist tenet does not follow a single method or approach. She resorts to presenting her views in rather wider, illusive, neither entirely deconstructive nor utterly structural, nor purely psychoanalytical. She differs from Gilbert in that she seeks for a new history or, as she prefers to call it, a "new woman". She calls for transformation, a change, a new system, free from the force of distinction. It is this tri-critical reading of woman as a tenor of that which is not fixed, definite or final that opens up the gate for a new theory of feminist writing. A woman is the very source and target, encoder and decoder of life. By placing woman within a postmodern unstable grand narrative frame, Cixous' deconstructs Jacques Lacan's phallocentrism and Sigmund Freud's "psychoanalytic closure", opening an inward-outward flow of narration, politically poignant and politically self-assuring.

Cixous' feminist idea is not a conventional one that deals with a woman from a subversive pattern. Her concern is not only the domination of patriarchy and its associatively constructed politics. Rather, she looks to the woman as a reverberating feminine force having a more superior and qualified power to that of man. According to Cixous, the feminine texture is above the masculine in that it contains within it the two dominating forces: the politics of desire and the poetics of supplier. She insists that women should write their bodies, that is, their writing should not be subversive, taking a defensive stand against the domination of patriarchy, but inwardly self- reflexive and outwardly self-assertive, combining contrapuntally what can be described as "prospective inscape".

Cixous feminine writing is "about the representation of the feminine body as a path towards thought, a thought that would question the foundations of male-centric thinking, that which would "unsilence" the female voice enabling them to manifest their unconscious hidden self or "the Other" in androcentric language". (Chakraborty, 2013, p. 2897)

"The Laugh of the Medusa" is a feminist postmodern manifesto per excellence. It contains the theoretical maxims of postmodern literary feminism. Cixous uses the myth of the Medusa as a deconstructive tool of the ever-held notions of woman as a passive being, deadly object and lacking body. Cixous's Woman is rather a "beautiful" Medusa. From semiotics to deconstruction and psychoanalysis through Freudian and Laconian speculations, Cixous develops a theory of woman that is polyphonic in self, multiple in culture, unstable in form, elusive in design and variations in texture. According to the Greek myth, Medusa was cursed by the goddess Minerva, transforming her into a monstrous figure with snake- like hair and a gaze that could turn anyone into stone. She was later killed by Perseus by slaying her head. Cixous utilizes the myth of Medusa as a fearful figure to interpret men's fear of wamen's voice, and act of killing her as men's attempt to silence her, "thus deconstructing Freud's theory of the 'castration complex' in men during the Oedipal stage of psychosexual development and the Lacanian theory of Symbolic Order in the development of language." (Chakraborty, 2013, p. 2898)

Hence, Cixous' Medusa is a parody of Freud's Medusa. In "Medusa's Head," Freud attempts to construe the symbolic idea of castration in males and how a male child tends to identify himself with the father for the fear of castration, thus associating himself with the presence of power and rejecting the world of absence and subservience. Cixous destabilizes 
Lacan's paradigm of Symbolic Order, giving priority to the unconscious, believing that women are "unlike their male counterparts closer to the imaginary and fantasies and far removed from fixed meanings and reasons." (Chakraborty, 2013, p. 2899) Women's language springs from the inner, from the suppressed instinctive power, an ever-streaming source of pleasure, a language that defies fixed meanings and representational codes. This power of writing will "give her access to her native strength: it will give her back her goods, her pleasures. . . her immense bodily territories which have been kept under seal." (Cixous, 1991, p.83)

Cixous' deconstruction of Lacan's theory of Symbolic Order is extended to the rethinking of Ludwig Klages' concept of Logocentrism. According to Cixous, Logo is a patriarchal term that underscores the presence of the male and the absence of the woman. In such cases, speech is classically conceived as original, authentic, and superior, while writing is thought of as secondary, derivative, "given" or even "parasitic."

Debunking Hegel's "patriarchal binary thought", Cixous,redefines male/female power relation through here theory of ecriture feminine. Structurally, Cixous asserts that by writing their body, they reposition their traditional symbolic order. They will never remain a passive signified. They will become a producer of meaning, an agent in identity making. Semiotically, ecriture feminine is a discourse of a multifaceted, pluralized and unstable new woman. The woman is a talking text and a written body; a political song and a poetic experience. She is diverse in tone, dynamic in position and cyclical in reepresentation. Chakraborty argues that Cixous "seeks to deconstruct the singular or linear writing that structures the masculine language". In so doing, "women operate from a plural, circular, and aimless economy and hence their language is plural as their plurality is contained in their sex organs . . . women's speech has always been dominated by the 'voice of the mother'". (Chakraborty, 2013, p. 2901) Cixous decries the western culture and its logos, which revolve around the phallus wherein the very notions of truth, reason and rationality are phallogocentric. Cixous uses a "deconstructive critique of western metaphysics as a system of oppositions"; a system where the oppositions are gendered (Bray, 2004, p. 24).

Building on Derida's theory, Cixous proposes the concept of "the other bisexuality" as an inventive to the older notion of masculine/feminine binaries. This concept is a doubleedged theorization of the feminine as a cultural and literary concept. Within the matrix of postmodernism, so to say, Cixous' woman" transposes the classical conception of bisexuality imprisoned with "castration fear". She obliterates the binary distinctions and adopts the concept of "in-between" as a floating term. It is writing in itself is "in-between", a bisexual act from within and without, the same and the other. "Women", she writes, that "benefitting from this vatic bisexuality which doesn't annul differences but stirs them up, pursues them, increases their number." By dissolving the old system of oppositions, bisexual writing enables sexuality to be represented by both male and female. She asserts her claim by providing examples of the German poet Kleist and Jean Genet who employed female libidinal economy or the female desire in their writing. (Cixous, 1976, pp. 883-84)

Feminine writing liberates both women and men - or, to say it otherwise, feminine thinking/feeling. "Write! Writing is for you, you are for you; your body is yours; take it," declares Cixous (Cixous, 1976, p. 246). Cixous advocates feminine writing to recognize and express the marginalized desires as summarized by Toril Moi "writing said to be feminine" or a "decipherable libidinal femininity, which can be read in writing produced by a male or a female". The feminine texts that this writing produces "strive in the direction of difference, struggle to undermine the dominant phallogocentric logic, split open the closure of binary 
opposition and revel in the pleasures of open-ended textuality" (Moi , 1985, p. 108). As Cixous puts it, the practice of feminine writing cannot be defined.

For this practice can never be theorized, enclosed, coded-which doesn't mean that it does not exist. But it will always surpass the discourse that regulates the phallocentric system; it does and will take place in areas other than those subordinated to philosophico-theoretical domination" (Cixous, 1976, p. 883).

It is writing which Moi describes, "As multiple, varied and ever-changing, consisting as it does of the non-exclusion either of the difference or of one sex" (Moi , 1985, p. 109). A point that I would like to stress about Cixous' concept of feminine writing (or feminine thinking/feeling) is the association of that writing with the postmodern trends of multiplicity and decentrality. Therefore, a characteristic of Cixous' feminine writing is "multiplication of the effects of the inscription of desire, over all parts of my body and the other body". As Cixous writes, "I have been amazed more than once by a description a woman gave me of a world all her own ... on the basis of systematic experimentation with the bodily functions, a passionate and precise interrogation of her erotogeneity . . my desires have invented new desires, my body knows unheard-of songs" (Cixous, 1976, p. 884).

Feminine writing, for Cixous, is a liberating term in literary and philosophical in intention. "Now, I - woman am going to blow up the Law: an explosion henceforth possible and ineluctable. . . in language." (Cixous, 1976, p. 887). In saying so, Cixous introduces her idea of third- way feminist school of thought, "the third body". An echo of this idea is found in her essays "Coming to Writing" and "The third Body." She defines the term to mean "all of us" not as a complementary thing but as a whole being. Abigail Bray comments on this by saying that Cixous uses the term cortically to dissolve the woman/man opposition by merging the masculine and feminine to create a body which defines the symbolic law and moves towards the limitless (Bray, 2004, pp. 62-63). The third body, which arises out of "desire the other for the other, whole and entire, male or female." (Cixous, 1976, p. 893)

A third body, Cixous theorizes, is considered Cixous's celebrating concept that opens a new vista in postmodern feminism. It includes in itself the idea of utilizing the economy of the self energy, the enculturating of the text and the representation of body in a bisexual, selfother whole. Thus, by re-thinking the Freudian concepts of the Id and libidio as a new way of writing, "the other bisexuality," and "the third body", Cixous sets out a postmodernist feminist culture. By adopting a rather Lacanian approach, she undoubtedly broadens the scope of Unconscious, giving the unconscious the power at work and the being of the self. This Lacanian perspective emphasizes the significance of language as a symbolic form of the structured Unconscious. Hence, the essay voices out a new feminist discourse based on multiplicity, instability, uncertainty and imagined spaces.

In their essay entitled "Angela Carter's Postmodern Medusa: An Endeavor to Break Patriarchy," Nadiha Aman, Sofia Dildar Alvi and Abdul Baseer argue that postmodern feminism "disproves the grand and imposing patriarch-narratives because they fix the identity of a woman". They believe that "language has always been exploited to incarnate patriarchy . . . to keep women passive, obedient and submissive". According to these postmodern feminists, "women should struggle to generate their own 'woman language' if they want to define themselves independently. In other words, "they become the Medusas that laugh at the current grand patriarchal-narratives". (Aman et al, 2014, p. 283) As such, Cixous' "The Laugh of the Medusa" establishes the canon of postmodern feminine writing, enabling women to write their sexuality, body and identity. It is a regenerating process of self-production into language and writing. Cixous's Écriture Feminine offers postmodern critical answers for 
women's queries of "identity" and "self". She declares: " I and the other, I as other . . I am thus of the species of travelers . . . the subject is a non-closed mix of self/s and others . . . an untranslatable phrase. Who can say who I are, how many I are, which I is the most I of my I's? . . . At the same time we are all the ages, those we have been, those we will be, those we will not be, we journey through ourselves." (Sellers, 2003, pp. xv-Xviii)

Language for Cixous is a means of reclaiming woman's self. It becomes a structural design of power exercise. Women should exercise their feminine power, decentralize the phalic, discover their potentials in writing. Feminine writing becomes the representational field in which the sign, the signifier and the signified merge in the third body experience. Here Cixous emphasizes the postmodernist view that sexuality and language are doppelganger of patriarchal ideology. In concord with this view, Craig Owens goes to say that "the postmodernist operation is being staged ... in order to expose the representational systems of the West that. . admit[s] only one vision. . . of representation as absolutely centered, unitary, masculine" (Owens, 1983, pp. 58-59).

Cixous finds in language a liberating force of the historical hinders that marginalize women. Feminine writing thus has the capacity to snare as well as to set us free from the clutches of male ideology through deconstructing and reconstructing processes. Writing is a transmutative process, an altering act of "the space that can serve as a springboard for subversive thought, the precursory movement of transformation of social and cultural structure" (Cixous, 1976, p. 879). It is this non-conformist sort of writing, the intensive use of femininity, the unconscious release of the suppresssed conscious by the phallus, and decentring the place which has ever been reserved in and by the symbolic that underpins Cixous' ecriture feminine and marks her essay as a key critical rampart of postmodern feminism. The purpose of écriture feminine is to destabilize phallogocentric discourses and the "feminine" should be understood as that which "exceeds being totally captured by logic" (Bray, 2004, p. 24). Hence, the rhythmic articulation of the mother's body is inscribed in the symbolic unison between the self and the m/other as jouissance of open-ended textually of "her body". It connotes the extreme pleasure derived from sexual orgasm. Sexual jouissance is like the female erotic, which cannot be theorized, enclosed or coded. (Phoca and Wright, 1999, pp. 53-55)

Feminism and postmodern philosophies aim at analyzing the given cultural codes and structures. In her essay, Cixous introduces two main principles about postmodern philosophy in relation to current feminist theory. Descriptively, feminist theory today becomes a form of postmodern trajectory as it seeks "to raise radical doubts about the unity and stability of the self, the reliability and independence of reason, the authority of truth, the neutrality of knowledge, and the transparency of language" (McGowan, 1988, pp. 196-97). The woman is an open-ended text, an uncertain event of unstable historicity, an open narrative discourse of glocal imaginary. In Cixous' view, feminine writing is a cry against totalitarian, essentialist and universalist discourse. Cixous treats the concept of the "feminine" within ahistorical rendering by rejecting the concept of "essence" with its claim of a natural defining core for persons and things.

The second principle is normatively related to unconscious politics. Feminine writing is a heterogeneous construction of body power, desire and economy. It is a philosophy of DE historicizing, destabilizing, and decentralizing the dominant concepts of fixed truth, reality and normative representation practiced by the male-centered society. In Helene Cixous: A Politics of Writing, Morag Schiach describes Cixous's definition of feminine writing as something that is "happening in the 'between', in that space which is uncertain" - in other 
words, a style of writing that focuses on "otherness" and pluralism and being "different" instead of being preoccupied with using secure fixed categories of stable identity. Feminine writing is therefore not afraid to go "outside narrative structures," as Schiach says, or to explore the unconscious, which stands outside the patriarchal logic and patriarchal discourse (Schiach, 1991, p. 22). Gender, as Anette Karjalainen argues, "is not neatly divided into two separate categories of "A" and "B," where "A" is "man" and "B" "woman," but instead Cixous suggests that the gender binary must be understood as "A" and "not A." (Karjalainen, 2010, p. 9) "Woman" is not defined as what she has that differs from "man," but in terms of what she lacks: she is defined as "not a man" and not as "woman", she is "the other" which further denotes the phallogocentrism of patriarchy (Cixous \& Clement, 1986, pp. 64-65).

\section{CONCLUSION}

Écriture feminine is very much a complex phenomenon that cannot quite be clearly defined or fixed and that is not only one of its characteristics/qualities but also its main point. Interestingly, Cixous's theory consists of an array of ideas and notions from Derrida's deconstruction through hermeneutics associated with the work of Hans-Georg Gadamer), critical theory (Juirgen Habermas, Theodor Adorno), Lacanian psychoanalysis, and Foucauldian analysis.

The main argument of Cixous about feminine writing is that it is an act of Bio-politics and politico-poetics that through expressing a specifically feminine voice "woman" will be able to free herself from patriarchy; through writing that specifically expresses female desire from the feminine body, or perspective, "woman" can become free. Furthermore, the patriarchal myth of "woman" and female desire, or perhaps her lack thereof, as explained further in her essay, is used against "woman" to keep her within the binary hierarchy where she is surpassed and subjugated by man.

The basic premise of Cixous' "The Laugh of the Medusa" is the supremacy of the woman to man as a multifaceted entity. She is at the center and the periphery. On the one hand, she represents womanhood, motherhood, and thus contains humanity within herself. On the other, she has the power of the body, sexuality, and desire or emotion; man is controlled by reason. He is limited in means and scope. By doing this, Cixous subverts and deconstructs the concept of Phallogocentrism and draws our attention to woman's free, open space.

\section{References}

Aman, N., Alvi, S. D., \& Baseer, A. (2014). Angela Carter's Postmodern Medusa: An Endeavor to Break Patriarchy. Interdisciplinary Journal of Contemporary Research in Business, 5(10), 282289.

Ares, T. (2009, 12 Nov.).Modern Matriarch, Feminist Body, Feminist Mind. Retrieved from http://modernmatriarch.wordpress.com/2007/05/15/feminist-body-feminist-mind-acomparative-analysis-of-helene-cixous-and-virginia-woolf-2/

Bray, A. (2004). Helen Cixous, Writing and Sexual Difference. Palgrave: Macmillan.

Chakraborty, D. (2013). Analyzing Ecriture Feminine in 'The Laugh of the Medusa. European Academic Research, 1(9), 2895 - 2904.

Cixous, H., \& Clement, C. (1986). The Newly Born Woman. Minneapolis : University of Minneapolis Press.

Cixous, H. The Laugh of the Medusa. (1976). Translated by C. Cohen \& C, Paula. Signs, 1(4), 875-93.

Cixous, H. (1991). Coming to Writing and Other Essays. Massachusetts: Harfard University Press. 
Leitch, V. B. (Ed). (2001). The Norton Anthology of Theory and Criticism: Helen Cixous (3rd ed.). New York: W.W. Norton \& Company.

Conley, A. V. (1984). Helen Cixous, Writing the Feminine. London: University of Nebraska Press

Conley, A. V. (1992). Helen Cixous. Toronto: University of Toronto Press.

Karjalainen, A. (Spring 2010). Deconstructing Sleeping Beauty. Södertörn University: The Institution for Culture \& Communication.

McGowan, D. T. (1988). Comment on Flax's 'Postmodernism and Gender Relations in Feminist Theory'. Signs, 14(1), 196-200.

Moi, T. (1985). Sexual/Textual Politics: Feminist Literary Theory. London: Methuen.

Owens, C. (1983). The Discourse of Others: Feminists and Postmodernism. In H. Foster (Ed.). The Anti-Aesthetic Essays On Postmodern Culture (2nd ed., pp 57-82). Washington: Bay Press.

Phoca, S., \& Wright, R. (1999). Introducing Postfeminism. New York: Totem Books Porsdam, H. (2016). Copyrighting Creativity: Creative Values, Cultural Heritage Institutions and Systems of Intellectual Property. London and New York: Routledge.

Schiach, M. (1991). Helene Cixous: A Politics of Writing. London and New York: Routledge.

Sellers, S. (Ed.). (2003). The Hélène Cixous Reader (2nd ed.). London and New York: Routledge.

Waldberg, P. (1965). Surrealism. New York: Thomas and Hudson.

Walker, M. (2001). Rehabilitating feminist politics and political theatre: Hélène Cixous's La Ville parjure ou leréveil des Erinyes at the Théâtre du Soleil. Modern \& Contemporary France, 9 (4), 495-506.

Warhol, R. R., Warhol-Down, R., \& Herndl, D. P. (Eds.). (1997). Feminisms: an anthology of literary theory and criticism. Rutgers University Press.

Žabić, S. (2001). Politics and Poetics of Hélène Cixous. Blesok, 23(1), 1-9. 